\title{
37. KD-1000システムによる胸部診断能のROC解析
}

ROC study of Chest Image Diagnosis with the Digital Radiography system ,KD-1000

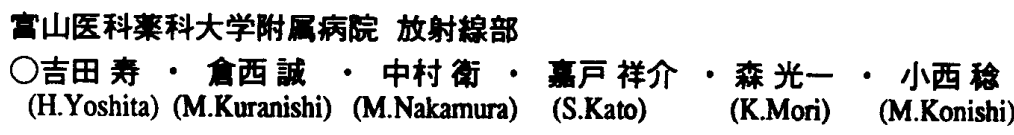

\section{1. 目的}

KD-1000(以下、KDと略す)システムと増感紙フィル ム(以下、SFと略す)システムを用いて撮影した胸部の 肺腫㿔性病変と間質性病変の画像をROC解析すること により、システム間の診断能を検証する。

\section{1 使用装置}

\section{2. 方法}

X線CT撮影装置 TCT900S (東芝),X線撮影装皆 HD$200 G$ (島津),DR装囯KD-1000(Konica), イメージング装置 KI-500 (Konica),レーザプリンターKFDR-P\& LP-4500 (Konica),增感紙/フィム KO-380/HRL (Konica/Fuji), 自動現像機 VX-400 (Konica)

\section{2 画鮴の収集と出力}

$\mathrm{KD}$ システムの画像の収集スベックは、画素サイ

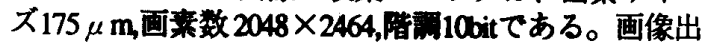
力に2種類のレーザブリンターを用い、スポット径が $87.5 \mu \mathrm{m}$ の六ッ切サイス（以下、KDハーフと略す） と、 $82.5 \mu \mathrm{m} て 2$ 倍拡大した半切サイス（以下 $\mathrm{KD} ラ イ$ フと略す) に出力した。㭪間はBell · spline间数を用 いた。SFシステムはKO-380とHRLを用いた。

\section{3 胸部提影と西敒分類}

単純撮影は通常のSFシステムとKDシステムを並行 して行った。撮影条件は再システムで同一（120kV$200 \mathrm{~mA}$-平均撮影時間 $16 \mathrm{msec}$, 聂影距鹳200 cm,Grid比 14:1 密度60本 $/ \mathrm{cm})$ である。また、1 1 週間以内には胸部CT 摄影を施行し部位の碓定福断を行った。一方、フイル ムは、SF群、KDハーフ群、KDライフ群の画像群に分 類した。

\section{4 対象部位}

フィルム上には診断梘野として $15 \mathrm{~cm} \times 15 \mathrm{~cm} （ \mathrm{KD}$ ハーフ群ては7.5cm ×7.5cm）の領域を設定し、CTで 確定した $5 \mathrm{~mm}$ 以上の腫瘾病変を含む領域31部位と間 賈病変を含む領城26部位を抽出した。正常対照とし てCT上病変のない領域を各疾患に対して同数抽出し た。

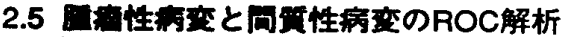

境影は室内光のもとシャーカステン上で放射線診 断医5名と致庴放射線技師3名で行った。画像群别の読 影間隔は2週間とした。ROC解析は、確信度を5段階に 設定し、各読影者のROC曲線と曲線下面積から $\mathrm{t}$ 検定 により有意差を求た。なお、使用したソフトウェアー はシカコ大学のMetz教投のもとて開器されたROCFT とCOROC2を使用した。

\section{3. 结果.}

Fig.1に厘瘤性痛变OROC曲線とFig.2に間壁性病変の ROC曲線また、Tab.1にROC曲的下面称の平均值と标 唓偏差を示す。

SF群とKDハーフ群の愿滰会影の福断能は同等であり ROC曲線下面稜の栍計的有竞差は認めなかった。一。 方、間質性病変では SF群と KDハーフ群、また、

\begin{tabular}{lccc}
\hline \hline & SF群 & KD-harf 群 & KD-life 群 \\
\hline 厘瘤性病変 & $0.889 \pm 0.049$ & $0.881 \pm 0.053$ & - \\
間䓄性病変 & $0.882 \pm 0.031$ & $0.842 \pm 0.035$ & $0.847 \pm 0.068$
\end{tabular}

Tab.1 ROC曲線下面積と標準倔差（読影者間の平均值）

SF群と KDライフ群で比較した。曲線下面積の有意差 はSF群とKDハーフ群で危険率2.2\%で認めた。

しかし、KDライフ群との比較では、SF群が有意の傾 向にあったものの統計的な有意差は 認められなかっ た。

\section{4. 考察}

腫嘴性病变にわけ るSF群とライフ群と の比較はあらかじめ 予測できたため行っ ていないが、間質性

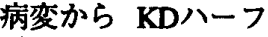
群と KDライフ群と の間で 診断能が異 なったことは、画像 として表現したとき にの出力装置を含め たシステム全体の視 覚系の違いが診断能 に影锌したものと思 われる。

\section{5. 结語}

KDシステムにお ける胸部単純写真の 読影を 目的として ROC解析により従来 からある増感紙フィ ルムシステムと比較 評価した。

KDシステムでは、

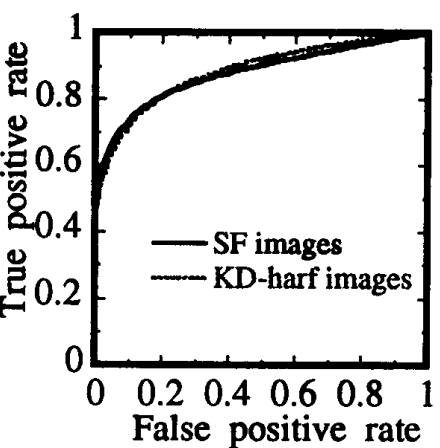

Fig.1 腫痹性病変のROC曲線

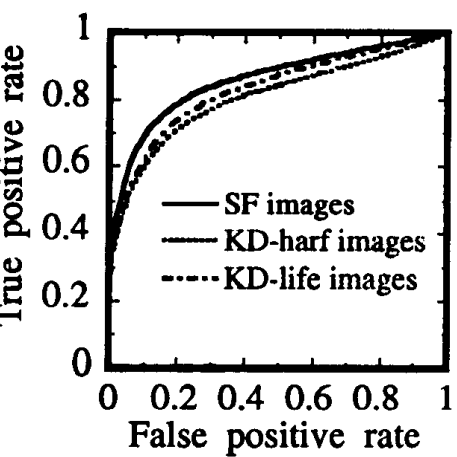

Fig .2 間貿性病变のROC曲線
胸部の腫痹性病変の診断は増感紙/フィルムシステムと 同等の能力を有していた。また、間質性病変においては ハーフ像て低下が見られるもののライフ像では有為差を 㑇ず、明確な差は琶めない。KDシステムでは、出力 形眧が笚一でないため、出力画像を含めた梘覚的な 能力の差が断能の还いとして表れた。

\section{锌}

最侥にROC眾析ソフトを提供して下さいましたMetzs 教投、並びに、画像部会の諸氏に然徱いたします。 